\title{
GAMBARAN KEBIASAAN IBU HAMIL DALAM MENGATASI KETIDAKNYAMANAN SELAMA KEHAMILAN DI RSUD R. SYAMSUDIN, SH
}

\author{
Vega Ramadhina Putri ${ }^{1}$, Lina Rahmiati ${ }^{2}$, \\ Khalidatunnur Andrianie ${ }^{3}$. \\ vegaramadhina@gmail.com \\ 1,2,3 Diploma Kebidanan Fakultas Kedokteran, Universitas Padjadjaran
}

\begin{abstract}
Pregnancy is a natural and normal process in reproductive period of women life. Discomfort of pregnancy period is common thing. During 9 months or at the 3 trimesters of pregnancy, pregnant women suffered physical change and also with her psychological to prepare herself for the growth period of the fetus, during labor, and breastfeeding. The such changes can cause interference and obstacles in pregnancy.

The purpose of research is to describe the habits of pregnant women how to resolve discomfort condition at R. Syamsudin, SH Hospital in May 2014.

This research used descriptive method with cross sectional approach by using 30 respondents as samples. For statistical analysis used is univariate.

Results of research are for first trimester are nausea and vomiting (100\%); second trimester are difficult defecation, bloating, and heartburn (50\%), third trimester is frequent urination (100\%). Base on the discomfort condition that happened, commonly practice by pregnant women is waiting for the discomfort goes away by itself.

The conclusions of research are the habit that did by pregnant women to resolve discomfort conditions is waiting for the discomfort goes away by itself.
\end{abstract}

Keywords : habit, discomfort during pregnancy

\section{PENDAHULUAN}

Kehamilan merupakan proses alami dan normal dalam kehidupan wanita pada masa reproduksi. Selama 3 bulan pertama atau pada trimester 1 kehamilan, wanita hamil mengalami perubahan-perubahan fisik maupun psikis untuk mempersiapkan pertumbuhan janin, masa persalinan dan juga menyusui. Keadaan perubahan yang terjadi dapat menimbulkan gangguan dan hambatan dalam kehamilan ${ }^{1}$.

Dari penelitian yang dilakukan oleh Diny Kurniawati pada tahun 2012, mengatakan bahwa mayoritas tingkat pengetahuan ibu hamil baik tentang ketidaknyamanan kehamilan di Puskesmas Tulis I sebanyak 18 orang $(60 \%)$ tingkat pengetahuannya sudah baik dan 12 orang (40\%) tingkat pengetahuan ibu hamil cukup tentang ketidaknyamanan kehamilan. Pada penelitian tersebut juga dikatakan sebanyak 16 orang $(53,3 \%)$ sudah bersikap positif dalam mengatasi ketidaknyamanan yang dilakukan, dan sisanya sebanyak 14 orang $(46,7 \%)$ masih bersikap negatif dalam mengatasi ketidaknyamanan yang dirasakan. Kondisi tersebut dapat dipengaruhi oleh tingkat pendidikan, pengalaman pribadi atau dari orang lain yang dianggap penting ${ }^{2}$. 
Kurangnya pengetahuan dari klien untuk menangani ketidaknyamanannya dapat menimbulkan bahaya. Pada awal kehamilan sampai usia 4 bulan (6 minggu), umumnya sering terjadi gangguan Morning Sickness. Gangguan bersifat individual. Dalam arti tidak semua ibu hamil akan mengalami gangguan morning sickness ini. Namun diperkirakan 50\%90\% ibu hamil akan mengalaminya. Berat ringannya gangguan ini tidak sama pada setiap ibu hamil dan kehamilannya. Dalam batas-batas tertentu keadaan ini masih normal, namun apabila muntah terjadi terus menerus sehingga mengganggu keseimbangan gizi dan cairan tubuh, kondisi ini didiagnosa sebagai Hyperemesis Gravidarum $^{3}$. Jika sudah terjadi hypermesis gravidarum maka seorang ibu hamil akan merasa kesulitan dalam mengkonsumsi makanan dan akan menyebabkan gizi kurang dan dapat menyebabkan pertumbuhan janin terganggu. Perkembangan janin sangat dipengaruhi oleh kecukupan zat gizi ibu. Saat gizi kurang, pertumbuhan janin terganggu. Status nutrisi ibu hamil yang baik maka janin yang dikandungnya akan baik dan kesehatan ibu sewaktu melahirkan akan terjamin. Sebaliknya jika keadaan kesehataan dan status nutrisi ibu hamil kurang baik, maka akan berakibat janin lahir mati dan bayi lahir dengan berat badan kurang dari normal yang dikenal dengan istilah berat badan lahir rendah ${ }^{4}$.

Tujuan umum penelitian ini adalah untuk mengetahui gambaran kebiasaan ibu hamil dalam mengatasi ketidaknyamanan selama kehamilan. Tujuan khusus dari penelitian ini adalah mengetahui ketidaknyamanan per trimester selama kehamilan yang sering ibu rasakan, mengetahui kebiasaan yang dilakukan hamil untuk mengatasi ketidaknyamanan yang dirasakan pada trimester 1, 2, dan 3 .

Dalam Kamus Besar Bahasa Indonesia disebutkan, kebiasaan adalah sesuatu yang biasa dikerjakan dan sebagainya; Antar pola untuk melakukan tanggapan terhadap situasi tertentu yang dipelajari oleh seseorang individu dan yang dilakukannya secara berulang untuk hal yang sama ${ }^{8}$. Pengertian lain menyebutkan kebiasaan adalah perilaku, yaitu suatu sikap atau kegiatan yang bersifat fisik atau mental, yang telah mendarah daging atau membudaya dalam diri seseorang ${ }^{9}$. Perbuatan kebiasaan tidak memerlukan konsentrasi perhatian dan pikiran dalam melakukannya. Kebiasaan dapat berjalan terus, sementara individu memikirkan atau memperhatikan hal-hal lain. Kebiasaan mengandung motivasi yang kuat, karena pada umumnya setiap orang yang bertindak berdasarkan force of habit sekalipun ia tahu, bahwa ada cara lain yang mungkin menguntungkan. Hal ini 
disebabkan oleh kebiasaan sebab cara yang mudah dan tidak memerlukan konsentrasi dan perhatian yang besar ${ }^{10}$.

Seorang psikolog menyatakan bahwa bahwa kebiasaan itu terbagi menjadi tiga kelompok, yaitu:

a. Kebiasaan yang bersifat otomatis seperti gerakan berjalan dan sejenis dengannya.

b. Kebiasaan gerak indra tubuh.

c. Kebiasaan gerakan berfikir ${ }^{10}$.

Tahapan pembentuk kebiasaan yaitu berawal dari memfokuskan perhatian kemudian mengulang-ulang dan praktik, lalu menunaikan pekerjaan tanpa berpikir atau merasa ${ }^{10}$.

Rasa tidak nyaman pada ibu hamil yang disebabkan oleh perubahan hormonal yang meliputi ketidaknyamanan pada trimester 1 berupa nyeri payudara, sering kencing, gusi berdarah, mengidam makanan, kelelahan, keputihan, ptyalism, pusing, mual dan muntah, pada trimester 2 berupa sulit $\mathrm{BAB}$, wasir, perut kembung, heartburn, serta ketidaknyamanan pada trimester 3 berupa sulit tidur, nyeri punggung.

\section{METODE PENELITIAN}

Penelitian ini menggunakan penelitian deskriptif dengan pendekatan potong lintang untuk menggambarkan kebiasaan ibu hamil dalam mengatasi ketidaknyamanan selama kehamilan. Populasi dalam penelitian ini adalah pasien yang memeriksakan kehamilan di RSUD R, Syamsudin. SH pada bulan April tahun 2014, yaitu sebanyak 78 ibu hamil. Pengumpulan data dilakukan dengan memberikan kuisioner kepada ibu hamil di poli kebidanan RSUD R. Syamsudin, SH. Pengumpulan data dilakukan selama satu minggu yaitu pada tanggal 2 sampai dengan tanggal 7 Juni 2014. Penulis menyebarkan kuesioner dan memperhatikan saat responden mengisi responden dan membantu responden jika terdapat bagian yang tidak dimengerti. Definisi operasional dari penelitian ini adalah sebagai berikut :

\begin{tabular}{|c|c|c|c|c|}
\hline Variabel & Definisi Operasional & $\begin{array}{l}\text { Cara } \\
\text { Ukur }\end{array}$ & Hasil Ukur & $\begin{array}{l}\text { Skala } \\
\text { ukur }\end{array}$ \\
\hline $\begin{array}{l}\text { Ketidaknyamanan } \\
\text { selama kehamilan }\end{array}$ & $\begin{array}{l}\text { Rasa tidak nyaman pada } \\
\text { ibu hamil yang disebabkan } \\
\text { oleh perubahan hormonal } \\
\text { yang } \\
\text { ketidaknyamanan pada } \\
\text { trimester 1 berupa nyeri } \\
\text { payudara, sering kencing, } \\
\text { gusi berdarah, mengidam } \\
\text { makanan, kelelahan, } \\
\text { keputihan, ptyalism, } \\
\text { pusing, mual dan muntah, }\end{array}$ & kuesioner & $\begin{array}{l}\text { a. Ya } \\
\text { b. tidak }\end{array}$ & Nominal \\
\hline
\end{tabular}




\begin{tabular}{|c|c|c|c|c|}
\hline & $\begin{array}{l}\text { pada trimester } 2 \text { berupa } \\
\text { sulit BAB, wasir, perut } \\
\text { kembung, heartburn, serta } \\
\text { ketidaknyamanan } \\
\text { trimester } 3 \text { berupa } \\
\text { tidur, nyeri punggung }\end{array}$ & & & \\
\hline $\begin{array}{l}\text { Kebiasaan dalam } \\
\text { mengatasi } \\
\text { ketidaknyamanan } \\
\text { dalam kehamilan }\end{array}$ & $\begin{array}{l}\text { Mengetahui perilaku atau } \\
\text { kegiatan yang dilakukan } \\
\text { ibu hamil untuk mengatasi } \\
\text { ketidaknyamanan yang } \\
\text { dirasakan selama trimester } \\
1,2 \text {, dan } 3\end{array}$ & kuesioner & $\begin{array}{l}\text { 1. Memeriksakan ke } \\
\text { tenaga kesehatan } \\
\text { 2. Pergi ke paraji } \\
\text { 3. Ditunggu sampai } \\
\text { hilang }\end{array}$ & Nominal \\
\hline
\end{tabular}

Analisis data yang digunakan adalah analisa secara univariat yang bertujuan untuk menjelaskan atau mendeskripsikan karakteristik dari setiap variabel penelitian $^{19}$. Dimana hasil penelitian dilakukan intrepretasi data dari item pertanyaan dengan cara menghitung presentase jawaban. Selanjutnya untuk setiap item yang dijawab diberi nilai sesuai dengan kategori yang telah ditentukan. Rumus uji univariat adalah sebagai berikut:

$$
P=-\underset{\mathrm{n}}{\mathrm{f}} \mathbf{x}
$$

Keterangan:

$$
\begin{aligned}
& \mathrm{P}=\text { presentase } \\
& \mathrm{f}=\text { frekuensi } \\
& \mathrm{n}=\text { populasi }
\end{aligned}
$$

\section{HASIL DAN PEMBAHASAN}

HASIL

\section{Gambaran rasa ketidaknyamanan yang dirasa serta kebiasaan yang dilakukan dalam kehamilan trimester 1}

Pada trimester 1 kehamilan ini, ratarata dari 10 responden merasakan mual dan muntah sebagai ketidaknyamanannya. Kebanyakan dari responden yang merasakan ketidaknyamanan pada trimester 1 ini lebih memilih untuk tidak memeriksakan ketidaknyamanannya dan menunggunya sampai hilang.

2. Gambaran rasa ketidaknyamanan yang dirasa serta kebiasaan yang dilakukan dalam kehamilan trimester 2

Pada trimester 2 rata-rata dari 10 responden mengalami keluhan yang hampir sama rata dirasakan, yaitu sulit buang air besar, perut kembung, dan heartburn. Pada trimester 2 ini, kebanyakan responden memilih untuk menunggu sampai hilang keluhan yang dirasakannya.

3. Gambaran rasa ketidaknyamanan yang dirasa serta kebiasaan yang dilakukan dalam kehamilan trimester 3

Pada trimester 3 kehamilan ini, rata-rata dari 10 responden mengalami sering kencing sebagai ketidaknymanannya. Kebanyakan dari responden yang merasakan ketidaknyamanan pada 
trimester 3 ini lebih memilih untuk tidak memeriksakan ketidaknyamanannya dan menunggunya sampai hilang.

\section{PEMBAHASAN}

\section{Gambaran rasa ketidaknyamanan yang dirasa serta kebiasaan yang dilakukan dalam kehamilan trimester 1}

Pada trimester 1 kehamilan terdapat 9 ketidaknyamanan yang umum dirasakan pada ibu hamil. Dari 9 ketidaknyamanan tersebut, yang paling banyak responden rasakan sebagai ibu hamil ada mual muntah. Meskipun belum diketahui penyebabnya, mual muntah dalam masa kehamilan berhubungan dengan perubahan kadar hormonal dalam tubuh wanita hamil. Ketika wanita hamil maka akan terjadi peningkatan kadar Hormon chorionic gonadotropin (HCG) yang berasal dari plasenta (ari-ari). Hormon ini berfungsi untuk menjaga kecukupan produksi hormon estrogen dan progesteron dari indung telur, yang berdampak pada kehamilan agar sehat dan lancar. Namun selain itu, hormon ini diduga berefek menimbulkan mual dan muntah terlebih pada tiga bulan kehamilan (trimester pertama) dan akan turun kembali setelah bulan keempat. Oleh karena itu mual muntah ini biasanya akan hilang dengan sendirinya setelah memasuki bulan keempat.
Disamping hormon HCG ini, hormon estrogen dianggap juga turut menjadi penyebab mual muntah pada wanita hamil $^{17}$. Beragam kebiasaan yang dilakukan dengan tujuan untuk mengurangi ketidaknyamanan yang dirasakan banyak dilakukan oleh responden sebagai ibu hamil. Pada pemeriksaan ke tenaga kesehatan, konseling pada umumnya diberikan, berkat konseling dari tenaga kesehatan klien menjadi mengerti mengenai ketidaknyamanan yang dialaminya serta cara mengatasinya, misalnya saja pada keluhan sering kencing tenaga kesehatan memberi konseling yang benar yaitu mengurangi minum air putih pada malam hari agar tidak mengganggu saat ibu tidur. Selain itu masih ada kebiasaan lain, dari kebiasaan-kebiasaan tersebut, yang paling sering adalah menunggu ketidaknyamanan tersebut hilang dengan sendirinya. Selain hal tersebut, untuk mengatasi ketidaknyamanan seperti mengidam makanan responden memilih untuk mengikuti mengidam tersebut.

Namun, selain hal tersebut diatas pada trimester ini masih ada pasien yang mendatangi paraji dengan tujuan untuk mengatasi ketidaknyamanan yang dirasakan.Hal ini tidak disarankan karena pemijatan bagian abdomen oleh 
paraji dapat memicu permasalahan baik pada janin dan baik pada ibu.

Dalam penelitian yang dilakukan oleh Elisa Yulia Kartika pada tahun 2013 dikatakan bahwa ada hubungan yang signifikan antara tingkat pengetahuan ibu hamil trimester III tentang tanda bahaya kehamilan dengan kepatuhan melakukan anc di wilayah kerja Puskesmas Lerep, Kec. Ungaran, Kab. $\quad$ Semarang $^{21}$. Kurangnya pengetahuan ini juga dapat diakibatkan karena ibu hamil ada yang tidak memeriksakan kehamilannya baik yang merasa terdapat ketidaknyamanan maupun yang tidak merasakannya. Seharusnya, jika klien merasakan ada ketidaknyamanan selama kehamilan, klien menyatakan ketidaknyamanan tersebut pada tenaga kesehatan agar dapat diberi pengertian sejauh mana ketidaknyamanan tersebut bersifat fisiologis dan diberi konseling yang baik agar tidak timbul masalah baru dari ketidaknyamanan yang dirasakan.

Kurangnya pengetahuan dari klien untuk menangani ketidaknyamanannya dapat menimbulkan bahaya, misalnya pada klien yang merasakan morning sickness dalam penelitian yang dilakukan oleh Nur Izzah pada tahun 2009 mengatakan Pada awal kehamilan sampai usia 4 bulan (6 minggu), umumnya sering terjadi gangguan
Morning Sickness. Gangguan bersifat individual. Dalam arti tidak semua ibu hamil akan mengalami gangguan morning sickness ini. Namun diperkirakan 50\%-90\% ibu hamil akan mengalaminya. Berat ringannya gangguan ini tidak sama pada setiap ibu hamil dan kehamilannya. Dalam batasbatas tertentu keadaan ini masih normal, namun apabila muntah terjadi terus menerus sehingga mengganggu keseimbangan gizi dan cairan tubuh, kondisi ini didiagnosa sebagai Hyperemesis Gravidarum ${ }^{3}$.

\section{Gambaran rasa ketidaknyamanan} yang dirasa serta kebiasaan yang dilakukan dalam kehamilan trimester 2

Pada trimester ini terdapat 4 ketidaknyamanan yang umum dirasakan pada trimester 2. Dari ketidaknyamanan yang umum terjadi tersebut, pada trimester ini tidak banyak responden sebagai ibu hamil yang merasakan ketidaknyamanan pada trimester ini. Adapun jumlahnya seimbang antara yang merasakan dan tidak merasakan.Terdapat 1 ketidaknyamanan yang tidak ada satupun responden rasakan yaitu wasir.Hal ini sesuai dengan teori yang mengatakan bahwa trimester kedua relatif terbebas dari segala ketidaknyamanan fisik, dan 
ukuran perut wanita belum menjadi masalah besar ${ }^{11}$.

Pada trimester kedua kehamilan terjadi sulit buang air besar hal ini dipengaruhi oleh karena peningkatan dari hormon progeseteron yang menyebabkan relaksasi otot sehingga usus kurang efisien, ditambah oleh penekanan rahim yang membesar di daerah perut, selain itu konsumsi suplemen zat besi/kalsium yang tidak diserap dengan baik oleh tubuh. Selain susah buang air besar, pada trimester ini juga ketidaknyamanan yang muncul adalah panas di bagian perut. Hal ini disebabkan oleh karena meningkatnya tekanan akibat rahim yang membesar dan juga pengaruh hormonal yang menyebabkan relaksasi otot saluran cerna sehinga mendorong asam lambung kearah atas ${ }^{1,16}$.

Pada trimester kedua ketidaknyamanan yang dirasakan lebih mengarah pada gangguan pencernaan seperti sulit buang air besar, perut kembung dan heartburn. Jika tidak ditangani secara benar, maka gangguan ini akan bertambah buruk, misalnya pada heartburn dapat mengganggu saat ibu tidur sehingga ibu tidak dapat beristirahat dengan baik.

Jumlah yang melakukan pemeriksaan ketidaknyamanan pada tenaga kesehatan pun seimbang dengan yang menunggu sampai keluhan tersebut hilang dengan sendirinya. Pada pemeriksaan ke tenaga kesehatan, konseling yang diberikan juga sudah sesuai dengan teori. Pada responden dengan keluhan sulit buang air besar, tenaga kesehatan memberi konseling untuk banyak meminum air putih ataupun banyak mengkonsumsi makanan yang mengandung serat. Selain melakukan pemeriksaan ke tenaga kesehatan dan menunggu sampai hilang, masih ada kebiasaan lain yang dilakukan responden, untuk keluhan perut kembung responden menggunakan minyak kayu putih di bagian perutnya untuk mengurangi ketidaknyamanan yang dirasakan.

3. Gambaran rasa ketidaknyamanan yang dirasa serta kebiasaan yang dilakukan dalam kehamilan trimester 3

Pada trimester 3 terdapat 3 ketidaknyamanan yang umum dirasakan oleh ibu hamil.Pada 3 ketidaknyamanan tersebut yang paling banyak dirasakan oleh responden sebagai ibu hamil adalah sering kencing.

Sering kencing pada kehamilan terjadi pada trimester 1 dan 3. Pada akhir kehamilan, bila kepala janin mulai turun ke bawah pintu atas panggul, keluhan sering kencing akan timbul lagi karena kandung kencing mulai tertekan 
kembali. Dalam kehamilan, ureter kanan dan kiri membesar karena pengaruh progesteron ${ }^{1}$.

Pada trimester ini presentase keluhan yang paling dirasakan ibu adalah sering kencing.Dari keluhan sering kencing ini, ibu hamil yang tidak melakukan penanganan dengan benar dapat terkena ISK. ISK telah diketahui berhubungan dengan kesudahankehamilan yang buruk, seperti persalinan preterm, pertumbuhan janin terhambat, bahkan janin lahir mati (stillbirth) ${ }^{18}$.

Pada trimester ini kebiasaan yang dilakukan untuk mengatasi ketidaknyamanan yang dirasakan adalah menunggu ketidaknyamanan tersebut sampai hilang dengan sendirinya. Terdapat perubahan kebiasaan pada trimester ini, pada trimester 3 ini ibu hamil yang merasakan ketidaknyamanannya lebih memilih untuk menunggu ketidaknyamanannya hilang dengan sendirinya, sedangkan pada trimester 1 keluhan ini lebih banyak diperiksakan, hal ini dapat disebabkan karena ibu hamil sudah mengetahui bahwa hal ini merupakan hal yang normal terjadi dan sudah mengetahui cara yang benar untuk mengatasi ketidaknyamanannya ini, selain menunggu sampai hilang, ada juga responden yang melakukan pemeriksaan ke tenaga kesehatan, pada saat pemeriksaan klien diberikan konseling yang sudah benar, misalnya untuk nyeri punggung tenaga kesehatan memberitahu cara mobilisasi yang benar.

Selain menunggu hilang dengan sendirinya masih ada kebiasaan lain yang dilakukan, adalah pergi ke tenaga kesehatan, pergi ke paraji untuk dilakukan pemijitan pada daerah punggung, selain itu melakukan hal lainnya seperti pada keluhan sulit tidur ada ibu yang mendengarkan musik agar dapat tertidur.

Pada keluhan ini, masih ada klien yang pergi ke paraji untuk melakukan pemijatan daerah punggung.Hal ini tidak menimbulkan masalah karena yang harus dihindari adalah pemijatan di daerah abdomen yang dapat membahayakan kondisi ibu dan janin itu sendiri.

\section{KESIMPULAN}

1. Ketidaknyaman yang paling sering terjadi pada trimester 1 adalah mual dan muntah. Sedangkan pada trimester 2 ketidaknyamanan seperti sulit buang air besar, perut kembung dan heartburn dirasakan seimbang antara ya dan tidak. Serta pada trimester 3 yang paling dirasakan adalah sering kencing. 
2. Pada trimester 1 kebiasaan yang paling banyak dilakukan untuk mengatasi beragam ketidaknyamanan yang dirasakan adalah menunggu sampai ketidaknyamanan tersebut hilang dengan sendirinya.

3. Pada trimester 2 kebiasaan yang dilakukan adalah seimbang antara yang melakukan pemeriksaan pada tenaga kesehatan dengan yang menunggu sampai keluhan tersebut hilang dengan sendirinya.

4. Pada trimester 3 lebih banyak responden yang menunggu sampai keluhan tersebut hilang dengan sendirinya.

\section{DAFTAR PUSTAKA}

Alonto, AM. Urinary Tract Infection.. In : Mahon, C.R., Lehman, D.C., Manuselis, G., editors. Diagnostics Microbiology. 3rd. Ed. Missouri:Saunders Elsevier. 2007.

Arikunto. Manajemen penelitian. Yogyakarta: Rineka Cipta, 2009.

Bennett VR, Brown LK. Myles Textbook for midwives eleventh edition. Edinburgh London Melbourne and new York. 1989.

Bolton $\mathrm{M}$, et al. Intrauterine growth restriction is a direct consequence of localized maternal uropathogenic Escherichia coli cystitis. PLoSOne. 2012

Cunningham FG, et al. 23rd ed. USA: McGraw-Hill; 2010.

Devy R, dkk. Perawatan kehamilan dalam perspektif budaya Madura di Desa Tambak dan Desa Rapalaok Kecamatan Omben Kabupaten Sampang. 2011.
www.journal.unair.ac.id/filerPDF/Pera watan Kehamilan dalam Perspektif Budaya Madura di Desa Tambak dan Desa Rapalaok Kecamatan Omben Kabupaten Sampang.pdf diakses tanggal 7 Juli 2014

Hillier SL, et al. Association between bacterial vaginosis and preterm delivery of a low-birth-weight infant. The new england journal of medicine 1995.

http://www.

perpusnwu.web.id/karyailmiah/docum ents/3321.docx. Semarang diakses tanggal 15 Agustus 2014.

Izzah N, dkk. Pengaruh kecemasan ibu hamil trimester I terhadap munculnya gangguan morning sickness di wilayah kerja Puskesmas Kusuma Bangsa Kota Pekalongan. 2009. www.journal.stikesmuh-pkj.ac.id diakses tanggal 11 maret 2014.

Kartika E, Setyowati H, Putu N. Hubungan Pengetahuan Ibu hamil trimester III tentang tanda bahaya kehamilan dengan kepatuhan ANC di wilayah kerja Puskesmas Lerep Kecamatan Ungaran. 2013.

King AL. Pengantar Psikologi Umum, Penerbit Salemba Humanika, Jakarta. 2005

Kurniawati D. Hubungan pengetahuan ibu hamil tentang ketidaknyamanan kehamilan dengan sikap dalam mengatasi ketidaknyamanan kehamilan di Puskesmas Tulis I Kec. Tulis Kab. Batang. 2012. www.jurnal.akbiduniska.ac.id diakses tanggal 7 Juli 2014.

Kusmiyati Y, dkk. Perawatan ibu hamil. Yogyakarta: Fitramaya. 2009

Kusnawara Y. hubungan infeksi saluran kemih dengan partus prematurus. Tesis fakultas kedokteran Universitas Diponegoro, 2001.

Lasala. Urinary Tract Infections: Managing Acute, Chronic and Difficult Cases. In : Culligan, P. Goldberg, R. Urogynecology in 
Primary Care. London: SpringerVerlag. 2007.

Notoatmojo S. Metodologi penelitian kesehatan. Jakarta: Rineka Cipta, 2010.

Rosyidah A. Tingkat Pengetahuan Ibu Hamil Trimester I Tentang Nutrisi Selama Kehamilan Di BPS Mitra Ibu Sragen Tahun 2013. www.digilib.stikeskusumahusada.ac.i d diakses tanggal 7 Maret 2014.

Susanti NN. Psikologi kehamilan. Jakarta: EGC, 2008

Tampubolon. Mengembangkan minat dan kebiasaan membaca pada anak. Bandung: Angkasa, 1993

Tim Penyusun Kamus Pusat Bahasa. Kamus besar bahasa Indonesia. Jakarta: PN Balai Pustaka, 2008

Varney H. Varney's midwifery, 4th ed. Jakarta : EGC, 2007: 232-7

Wilie, L. Essential anatomy and physiology in maternity care. 2th ed. Elsevier Churchill livingstone. Scotland. 2005. 